\title{
Solar Tracker Elektro-Pneumatik Berbasis Kendali Fuzzy
}

\author{
Baisrum $^{1}$, Budi Setiadi², Sarjono Wahyu Jadmiko ${ }^{3}$, Sudrajat $^{4}$, Varian Andika \\ Wijayakusuma $^{5}$, Fryma Zhafran Raihan ${ }^{6}$ \\ 1,2,3,4 Jurusan Teknik Elektro, Politeknik Negeri Bandung, Indonesia \\ ${ }^{5,6}$ Teknik Otomasi Industri, Jurusan Teknik Elektro, Politeknik Negeri Bandung, Indonesia
}

Email: $\underline{\text { baisrum@polban.ac.id }}{ }^{1}, \underline{\text { budi.setiadi@polban.ac.id }}{ }^{2}, \underline{\text { sarjono@polban.ac.id }}$, sudrajat@polban.ac.id ${ }^{4}$, varian.andika.toi17@ polban.ac.id ${ }^{5}$,

fryma.zhafran.toi17@polban.ac.id ${ }^{6}$

Received 01 October 2020| Revised 10 October 2020| Accepted 27 October 2020

\begin{abstract}
ABSTRAK
Salah satu faktor yang mempengaruhi daya keluaran listrik dari panel surya adalah posisi dan tingkat penyerapan sinar UV (Ultraviolet) dari matahari. Penggunaan aktuator motor servo untuk solar tracker membebani listrik yang dihasilkan dari pembangkit internal panel surya. Pada penelitian ini dirancang solar tracker menggunakan silinder pneumatik sebagai pengganti aktuator motor servo. Sedangkan, sensor UV digunakan untuk memantau sudut pergerakan matahari. Nilai error dan $\Delta$ error dari hasil pengolahan data sensor UV menjadi masukan bagi sistem pengambilan keputusan berbasis kendali fuzzy. Keluaran sistem pengambilan keputusan ini mengatur pergerakan posisi silinder pneumatik naik, turun, atau stop. Pengujian perangkat bekerja dengan baik, menghasilkan respon dinamik overshoot 5,3\% dan error steady state 1,6\%.
\end{abstract}

Kata kunci: ultraviolet, pneumatik, fuzzy, overshoot, error

\begin{abstract}
One of the factors that affect the electrical output power of solar panels is the position and the absorption level of UV (Ultraviolet) rays from the sun. The use of a servo motor actuator for solar trackers burdens the generated electricity from the solar panels internal generator. In this study, a solar tracker was designed using a pneumatic cylinder as a replacement for the servo motor actuator. While a UV sensor was used to monitor the angle of the sun's movement. The error and $\Delta$ error values from UV sensor data processing results become an input for decision-making systems based on fuzzy control. The output of this decision-making system regulates the movement of the position of the pneumatic cylinder up, down, or stopping. The test device worked properly, resulting in a dynamic response overshoot of $5.3 \%$ and a steadystate error of $1.6 \%$.
\end{abstract}

Keywords: ultraviolet, pneumatic, fuzzy, overshoot, error 


\section{PENDAHULUAN}

Pembangkit listrik tenaga angin dan matahari termasuk kategori pembangkit listrik terbarukan. Daya keluaran maksimum pada pembangkit listrik tersebut, sangat dipengaruhi posisi sudut turbin angin dan panel surya [1] [2]. Posisi sudut maksimum dari angin, sinar matahari tidak dapat diprediksi berdasar kalender dan waktu. Agar mendapatkan posisi sudut yang baik, generator turbin angin dan panel surya digerakan menggunakan tracker otomatis dengan aktuator motor servo [4] [5] [6] [7]. Integrasi motor servo-generator turbin angin dan motor servo-panel surya, arah gerakan rotasi translasi mengikuti masukan dari sensor [10] [12].

Penggunaan motor servo sebagai aktuator untuk menggerakan posisi sudut generator turbin angin atau panel surya memiliki kekurangan. Pasokan energi listrik untuk menggerakan motor servo berasal dari pembangkit internal yang dihasilkan [8] [9]. Dampak dari penggunaan motor servo adalah berkurangnya daya keluaran listrik untuk ke jaringan beban [11] [13].

Penelitian ini bertujuan untuk melihat respon dinamik dari kombinasi elektro-pneumatik pada sistem solar tracker. Perubahan posisi sudut solar tracker digerakkan secara mekanik. Komponen mekanik yang digunakan sebagai aktuator solar tracker adalah tipe silinder pneumatik kerja ganda. Silinder pneumatik bergerak naik, turun, atau stop menggunakan sumber energi angin yang alirannya diatur melalui 4 katup digital dan 2 katup proporsional. Sedangkan untuk kendalinya menggunakan sistem elektronik berbasis fuzzy. Sensor UV untuk memantau sudut pergerakan matahari difungsikan sebagai umpan balik atau masukan bagi sistem pengambilan keputusan kendali fuzzy. Sebelumnya nilai masukan sensor UV diperbaharui menjadi variabel error dan $\Delta$ error. Keluaran sistem pengambilan keputusan fuzzy sugeno digunakan untuk mengatur katup digital dan proporsional.

\section{METODOLOGI PENELITIAN}

\subsection{Plant Solar Tracker}

Gambar 1 menunjukkan realisasi solar tracker. Modul ini terdiri dari perangkat pneumatik dan elektronik. Modul ini dibangun pada skala laboratorium untuk kebutuhan penelitian dan pengajaran dengan ukuran panjang $80 \mathrm{~cm}$, lebar $65 \mathrm{~cm}$, dan tinggi $70 \mathrm{~cm}$. Kapasitas berat beban panel surya yang digunakan $1 \mathrm{Kg}$ dengan daya $6 \mathrm{WP}$. 


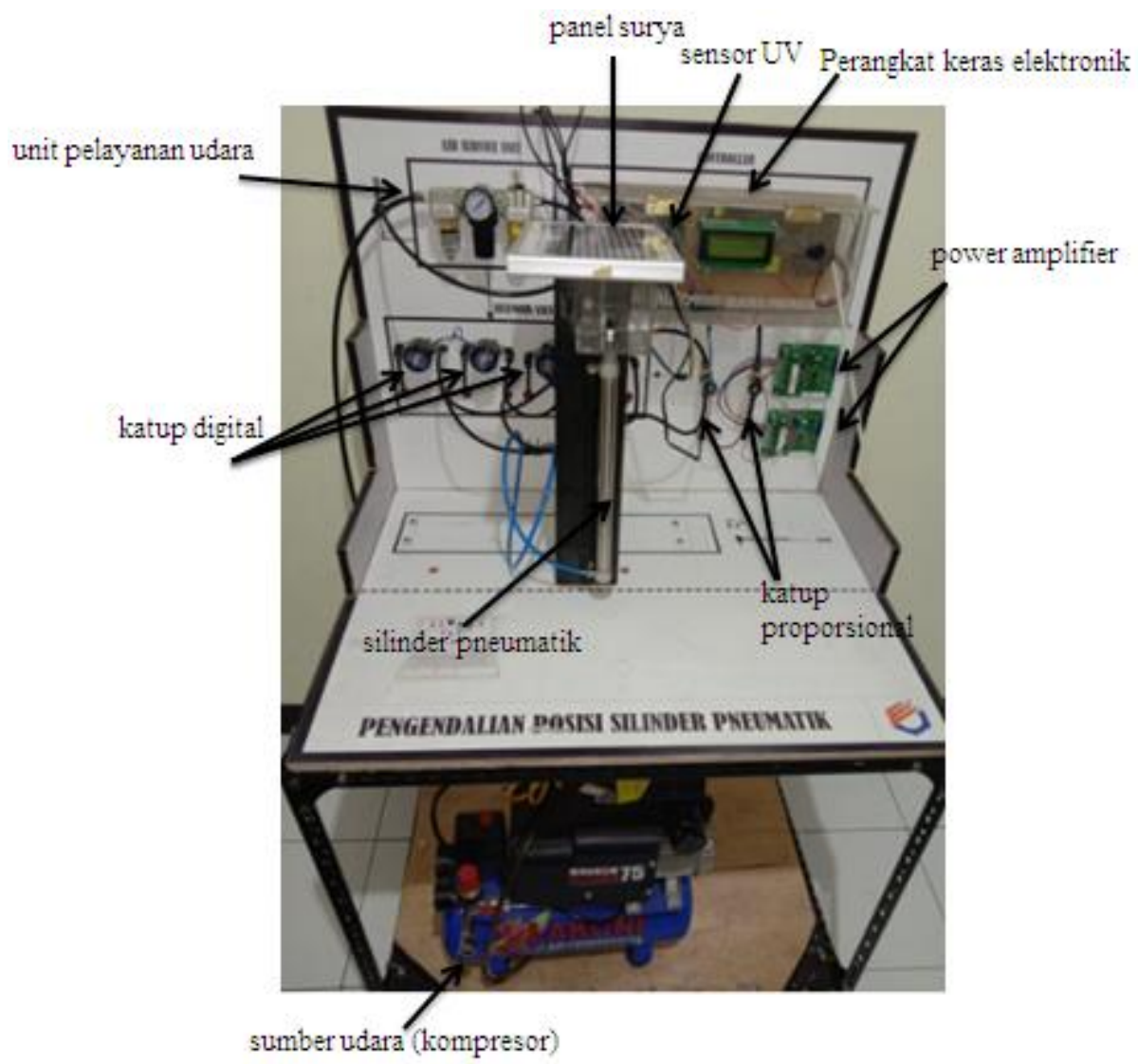

Gambar 1. Realisasi solar tracker

\subsection{Desain Perangkat Keras Elektronik}

Gambar 2 menunjukkan desain sistem perangkat keras elektronik untuk solar tracker. Sistem terdiri dari perangkat masukan, proses, dan keluaran. Perangkat masukan terdiri dari sensor UV dan potensiometer. Sensor UV berfungsi untuk memantau pergerakan posisi matahari dan potensio berfungsi untuk kalibrasi nilai setpoint. Mikrokontroler berfungsi untuk pengolah data sensor dan pengambilan keputusan pergerakan silinder pneumatik berbasis kendali fuzzy. Perangkat keluaran terdiri atas driver L298D, DAC (digital to analog converter), power amplifier, dan LCD (liquid crystal display). L298D difungsikan sebagai penguat arus untuk mengaktifkan koil katup digital. DAC berfungsi untuk mengubah data hasil keluaran fuzzy menjadi bentuk tegangan 1 sampai dengan $5 \mathrm{Vdc}$. Power amplifier berfungsi untuk mengubah besaran tegangan 1 sampai dengan $5 \mathrm{Vdc}$ menjadi tegangan 0 sampai dengan $24 \mathrm{Vdc}$ untuk mengatur bukaan katup proporsional. LCD berfungsi untuk menampilkan informasi data hasil pengukuran. 
masukan

proses

keluaran

mekanik pneumatik

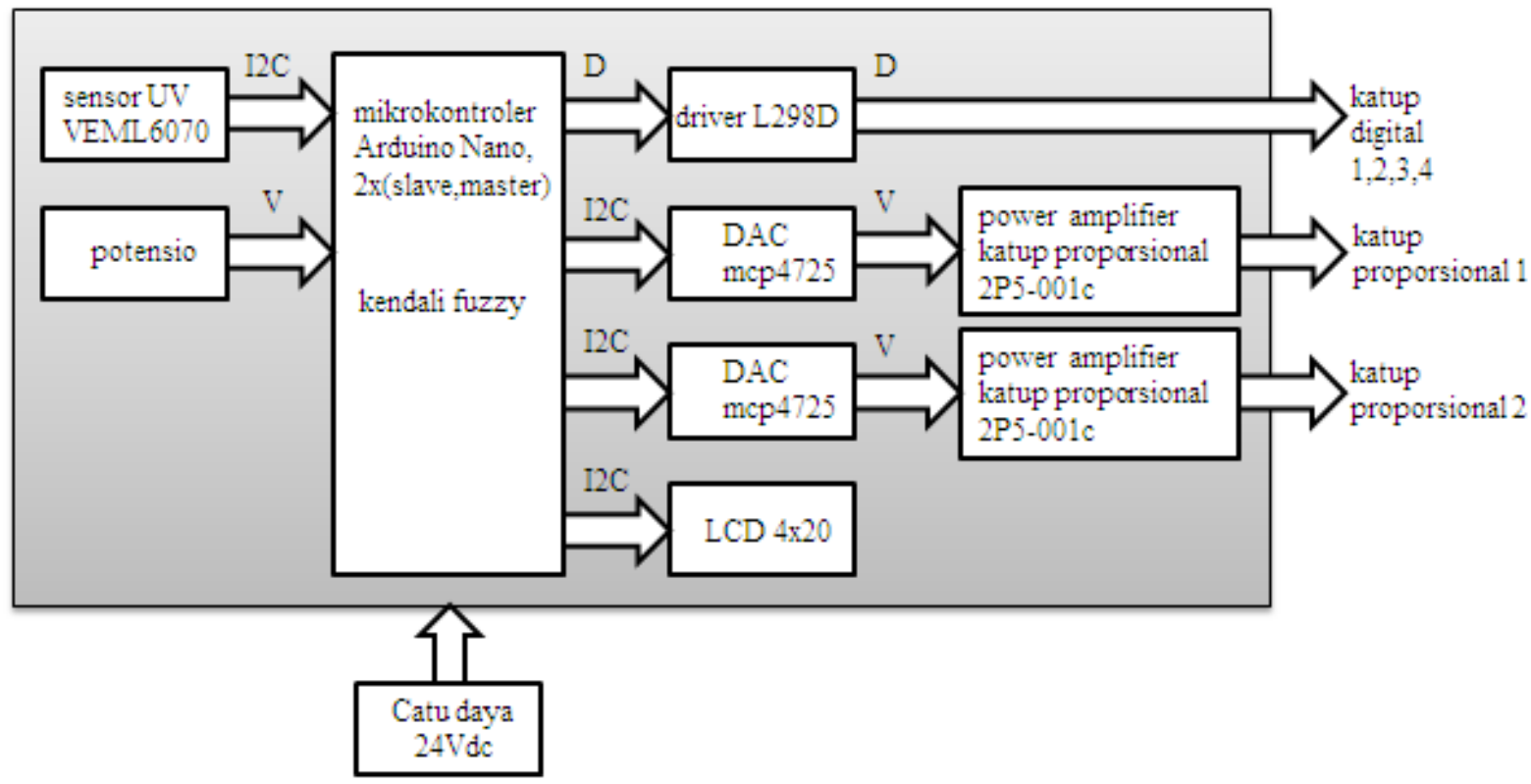

Gambar 2. Desain perangkat keras elektronik

Berikut detail spesifikasi perangkat keras elektronik, seperti ditunjukkan pada Tabel 1.

Tabel 1. Spesifikasi perangkat keras elektronik

\begin{tabular}{cll}
\hline No & komponen & Keterangan \\
\hline 1 & VEML6070 & sensor UV, I2C, 2.7-5.5, indek UV, indek infra-red, float \\
2 & potensio & karbon, $10 \mathrm{~K} \Omega-1 / 4 \mathrm{~W}$ \\
3 & mikrokontroler & ATMega8, berbasis Arduino uno \\
4 & L298D & H-bridge ganda, mak 32 Vdc/5 A \\
5 & MCP4725 & DAC 8-bit, I2C, 5 Vdc \\
6 & LCD & 4x20 karakter,I2C \\
7 & power amplifier & Masukan tegangan 1-5 Vdc, keluaran 0-24 Vdc, 4W \\
\hline
\end{tabular}

\subsection{Desain Mekanik Pneumatik}

Gambar 3 menunjukkan desain sistem perangkat keras pneumatik. Desain sistem terdiri dari perangkat aktuator silinder pneumatik kerja ganda, 4 buah katup digital, 2 buah katup proporsional, unit pelayanan udara, sumber udara, peredam suara dan tampilan sensor tekanan. Silinder pneumatik berfungsi sebagai aktuator untuk mendorong naik, turun atau stop solar tracker, melalui pengaturan katup digital. Sedangkan katup proporsional berfungsi untuk mengendalikan kecepatan pergerakan silinder pneumatik melalui pengaturan aliran udara yang masuk maupun keluar. Besarnya bukaan katup proporsional 0 sampai dengan $20 \%$. Kedua bukaan katup dirancang sama untuk menjaga tekanan silinder tetap stabil. Unit pelayanan udara memiliki 3 fungsi, yaitu menyaring unsur air dalam udara, pengaturan tekanan, tampilan, dan pelumasan. Sensor tekanan berfungsi untuk tampilan tekanan. Peredam suara berfungsi untuk menyaring kotoran dan debu dari luar sistem. 


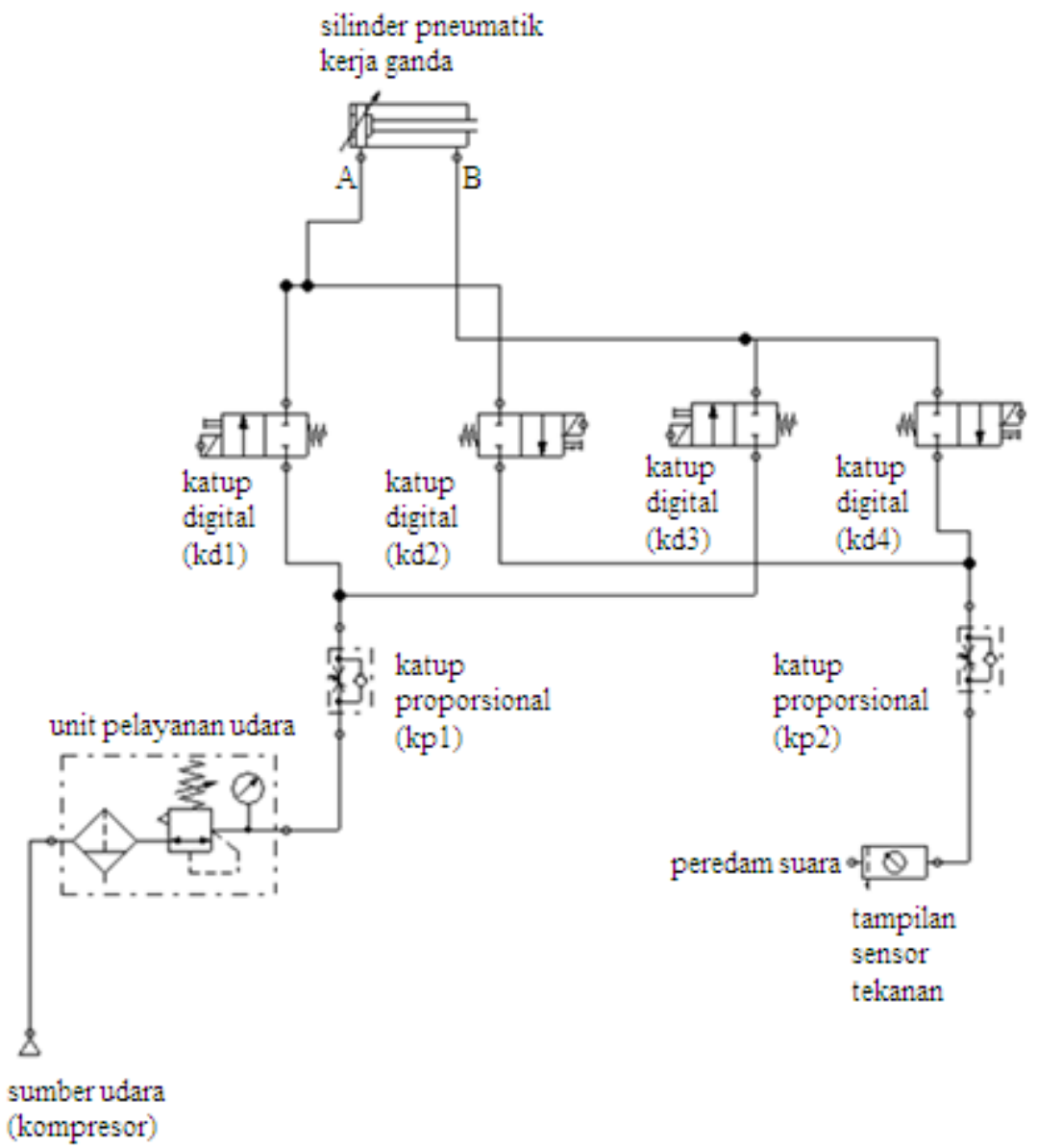

Gambar 3. Desain perangkat keras pneumatik

Berikut mode deskripsi kerja sistem silinder pneumatik, seperti ditunjukkan pada Tabel 2.

Tabel 2. Deskripsi kerja silinder pneumatik

\begin{tabular}{|c|c|c|c|c|c|c|c|c|}
\hline mode & $\mathrm{kd} 1$ & $\mathrm{kd} 2$ & $\mathrm{kd} 3$ & $\mathrm{kd} 4$ & $\begin{array}{c}\mathrm{kp} 1 \\
\operatorname{masukan}(\%)\end{array}$ & $\begin{array}{c}\mathrm{kp} 2 \\
\text { luaran }(\%)\end{array}$ & $\begin{array}{c}\text { silinder } \\
\text { pneumatik }\end{array}$ & keterangan \\
\hline $\mathrm{m} 1$ & $\mathrm{ON}$ & OFF & OFF & ON & $0,1 \mathrm{~s} / \mathrm{d} 20$ & $0,1 \mathrm{~s} / \mathrm{d} 20$ & naik & aliran \\
\hline $\mathrm{m} 2$ & OFF & ON & $\mathrm{ON}$ & OFF & $0,1 \mathrm{~s} / \mathrm{d} 20$ & $0,1 \mathrm{~s} / \mathrm{d} 20$ & turun & aliran uda \\
\hline $\mathrm{m} 3$ & OFF & OFF & OFF & OFF & 0 & 0 & stop & $\begin{array}{l}\text { aliran udara terkunci } \\
\text { didalam silinder }\end{array}$ \\
\hline
\end{tabular}

Spesifikasi lengkap sistem pneumatik yang dirancang ditunjukkan pada Tabel 3. Komponen yang digunakan dipilih dengan mempertimbangkan biaya dan spesifikasi modul yang dibuat dalam bentuk teknologi tepat guna. Komponen yang digunakan merupakan standar industri proses yang sebenarnya.

Tabel 3. Spesifikasi perangkat keras pneumatik

\begin{tabular}{cll}
\hline No & komponen & Keterangan \\
\hline 1 & silinder pneumatik & kerja ganda, langkah $250 \mathrm{~mm}, \varnothing$ tabug $20 \mathrm{~mm}$, selang $6 \mathrm{~mm}$ \\
2 & katup digital & $2 / 2$, pegas, koil 24 Vdc, selang $6 \mathrm{~mm}$ \\
3 & katup proporsional & satu arah, $1 / 8,0.7 \mathrm{Mpa}$, analog $24 \mathrm{Vdc} / 4 \mathrm{~W}$, selang $6 \mathrm{~mm}$ \\
4 & unit pelayanan udara & lubrikan, regulator, oil, $10 \mathrm{bar}$, selang $8 \mathrm{~mm}$ \\
5 & sumber udara & $3 / 4 \mathrm{HP}, 220 \mathrm{Vac}$ \\
\hline
\end{tabular}

Gambar 4 menunjukkan prinsip kerja solar tracker. Solar tracker untuk menghasilkan titik penyerapan UV maksimum, bergerak satu sumbu dari $-22,5^{\circ}$ sampai $22,5^{\circ}$. Sensor yang digunakan untuk memantau 
pergerakan matahari adalah UV. Sensor ini bekerja berdasarkan penyerapan sinar UV dengan indek 0 sampai 14 floating point. Alasan penggunaan sensor UV dikarenakan penyerapan nilai indek UV berbanding lurus dengan energi listrik yang dihasilkan, seperti ditunjukkan pada Persamaan (1).

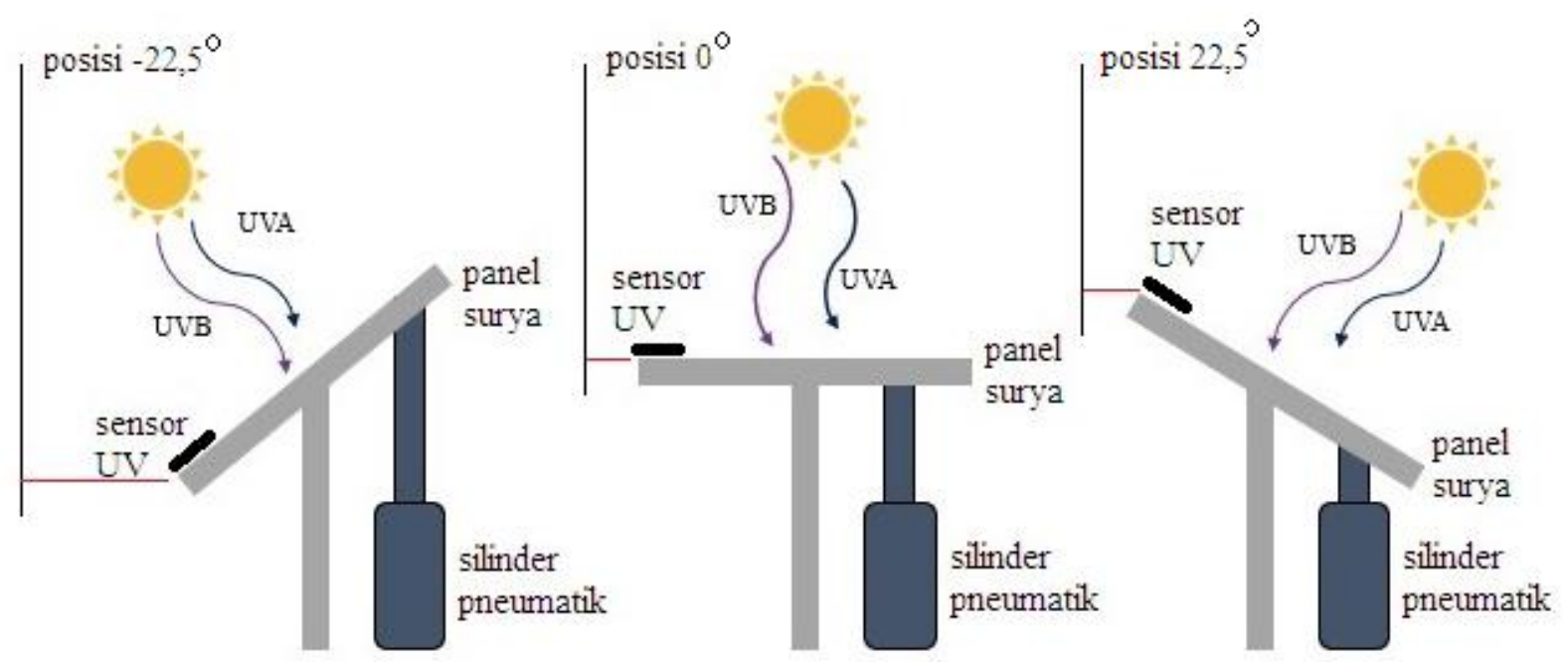

Gambar 4. Prinsip kerja solar tracker

\subsection{Desain Perangkat Lunak}

Gambar 5 menunjukkan sistem kendali fuzzy.

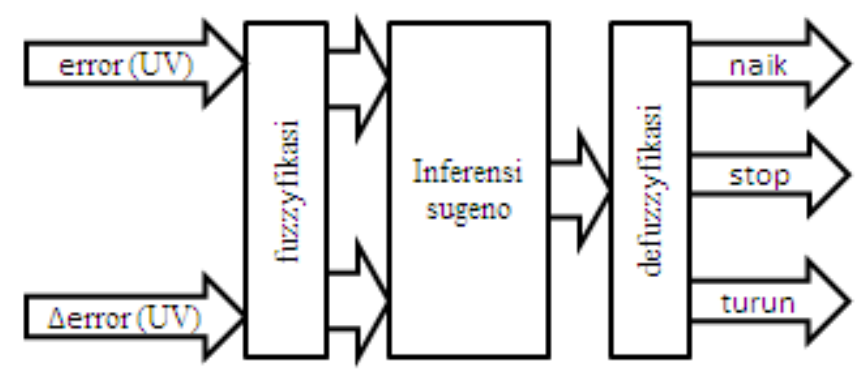

\section{Gambar 5. Diagram blok kendali fuzzy}

Masukan kendali fuzzy adalah error dan $\Delta$ error yang didapat dari sensor UV. Selanjutnya dicari nilai derajat keanggotaannya. Hasil nilai derajat keanggotaan dilakukan proses $A N D$ dan selanjutnya diinferensi dengan metode sugeno. Keluaran dari proses inferensi adalah nilai yang masih bersifat fuzzy, sehingga dilakukan defuzzyfikasi. Nilai keluaran selanjutnya digunakan untuk pengambilan keputusan apakah silinder peumatik bergerak naik, turun atau stop.

Data masukan error dan $\Delta$ error diperoleh dari fungsi waktu, seperti ditunjukkan pada Persamaan (2) dan Persamaan (3).

$$
\begin{gathered}
\operatorname{error}(t)=r(t)-y(t) \\
\operatorname{\Delta error}(t)=\operatorname{error}(t)-\operatorname{error}(t-1)
\end{gathered}
$$

Dimana $\mathrm{r}(\mathrm{t})$ adalah nilai setpoint merupakan referensi yang diinginkan, $\mathrm{y}(\mathrm{t})$ adalah nilai keluaran, error $(\mathrm{t})$ adalah nilai error saat ini, dan error(t-1) adalah nilai error sebelumnya. Fungsi keanggotaan masukan error kendali fuzzy, seperti ditunjukkan pada Gambar 6. Sedangkan, fungsi keanggotaan masukan $\Delta$ error, seperti ditunjukkan pada Gambar 7. Gambar 8 menunjukkan fungsi keanggotaan dengan 5 himpunan linguistic berupa pulsa untuk menghasilkan keluaran yang lebih smooth. Sedangkan, 
basis aturan fuzzy yang dirancang seperti ditunjukkan pada Tabel 4. Hasil simulasi perancangan kendali fuzzy dari sistem solar tracker, seperti ditunjukkan pada Gambar 9 sampai dengan Gambar 12. Gambar 9 menunjukkan hubungan antara masukan dan keluaran. Nilai masukan error dan $\Delta$ error mempengaruhi arah pergerakan aliran udara pada katup digital (negatif silinder pneumatik turun, positif silinder pneumatik naik, 0 silinder pneumatik stop). Sedangkan, besar kecil nilai negatif, positif mempengaruhi persentasi bukaan katup proporsional dan berdampak pada kecepatan pergerakan silinder pneumatik. Gambar 10 menunjukkan pengujian silinder pneumatik naik dengan nilai error positif 12, dan $\Delta$ error 0 menghasilkan nilai positif 9,49. Skala 0 sampai dengan 24 dan sebaliknya menunjukkan persentasi bukaan katup proporsional. Skala 0 menunjukkan katup tertutup, dan skala 24 atau -24 menunjukkan katup terbuka maksimum. Gambar 11 menunjukkan pengujian silinder pneumatik turun dengan nilai error negatif 12, dan $\Delta$ error 0 menghasilkan nilai negatif 9,49. Gambar 12 menunjukkan pengujian silinder pneumatik turun dengan nilai error 0 , dan $\Delta$ error 0 menghasilkan nilai 0 .

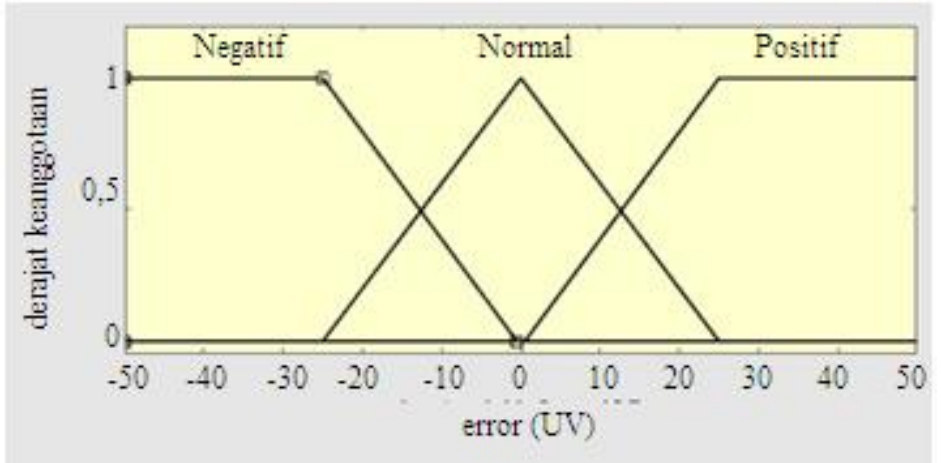

Gambar 6. Fungsi keanggotaan masukan error (UV)

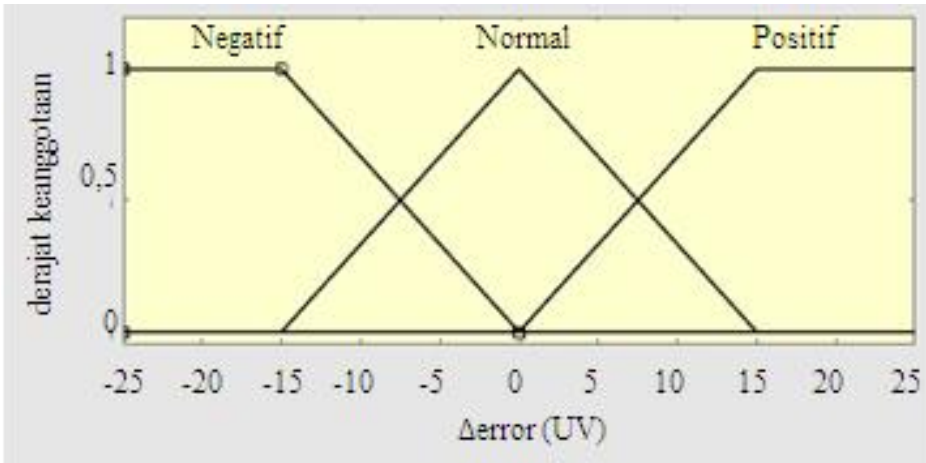

Gambar 7. Fungsi keanggotaan masukan $\Delta$ error (UV)

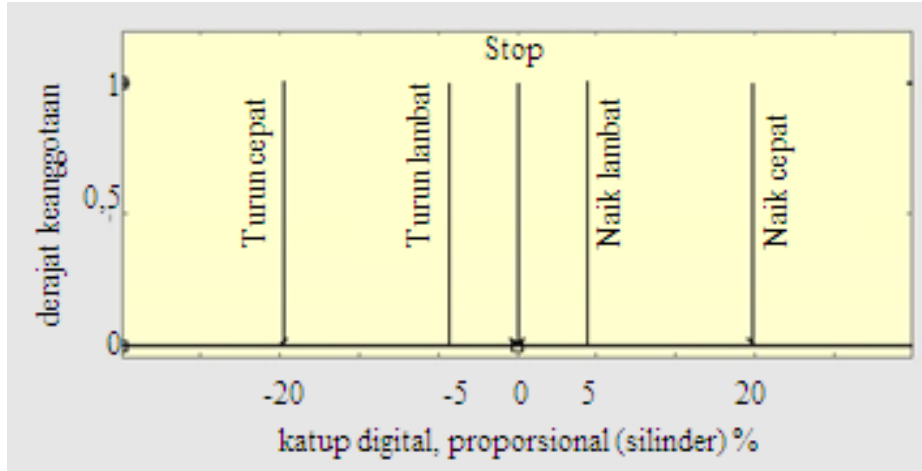

Gambar 8. Fungsi keanggotaan keluaran katup digital, proporsional (silinder)

Tabel 4. Aturan fuzzy 


\begin{tabular}{cccc}
\hline No & $\begin{array}{c}\text { masukan } \\
\text { error (UV) }\end{array}$ & $\begin{array}{c}\text { masukan } \\
\text { serror (UV) }\end{array}$ & $\begin{array}{c}\text { keluaran katup digital, } \\
\text { proporsional (silinder) }\end{array}$ \\
\hline 1 & Negatif & Negatif & Turun cepat \\
2 & Negatif & Normal & Turun cepat \\
3 & Negatif & Positif & Turun lambat \\
4 & Normal & Negatif & Turun lambat \\
5 & Normal & Normal & Naik lambat \\
6 & Normal & Positif & Naik lambat \\
7 & Positif & Negatif & Naik cepat \\
8 & Positif & Normal & Naik cepat \\
\hline
\end{tabular}

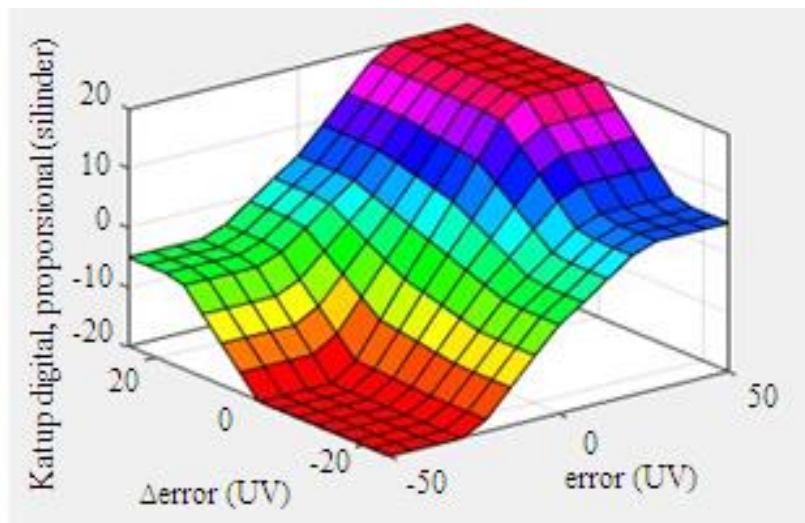

Gambar 9. Grafik hubungan masukan dan keluaran

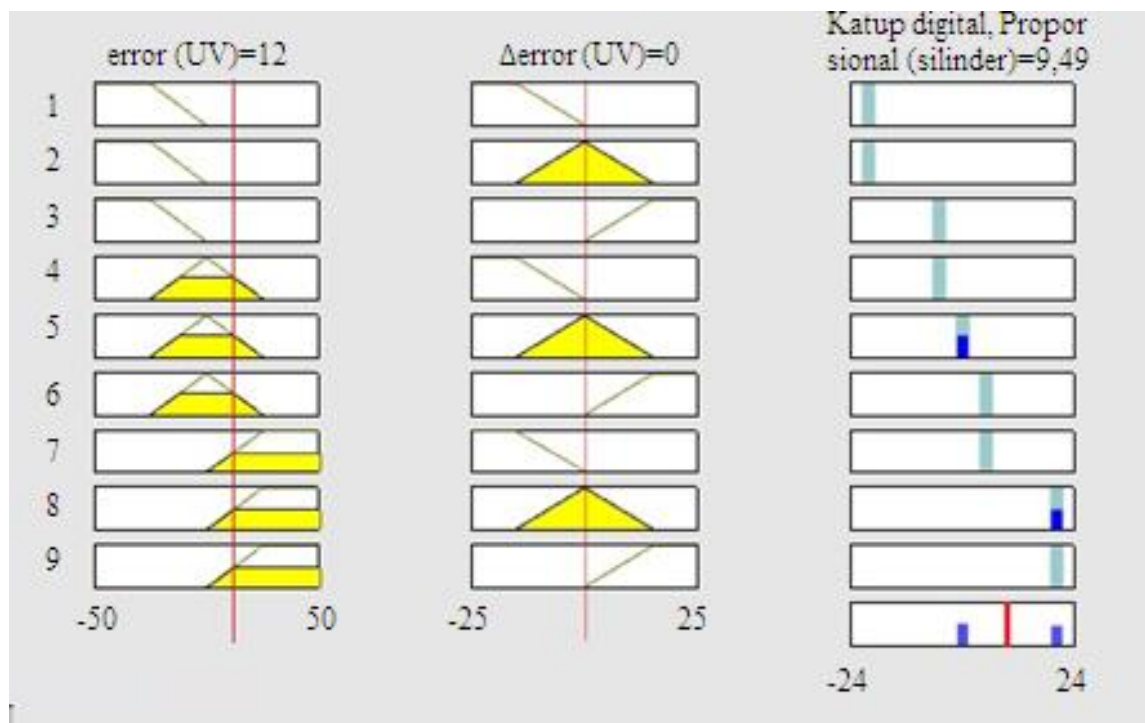

Gambar 10. Tampilan aturan $f u z z y$ dengan keluaran naik 


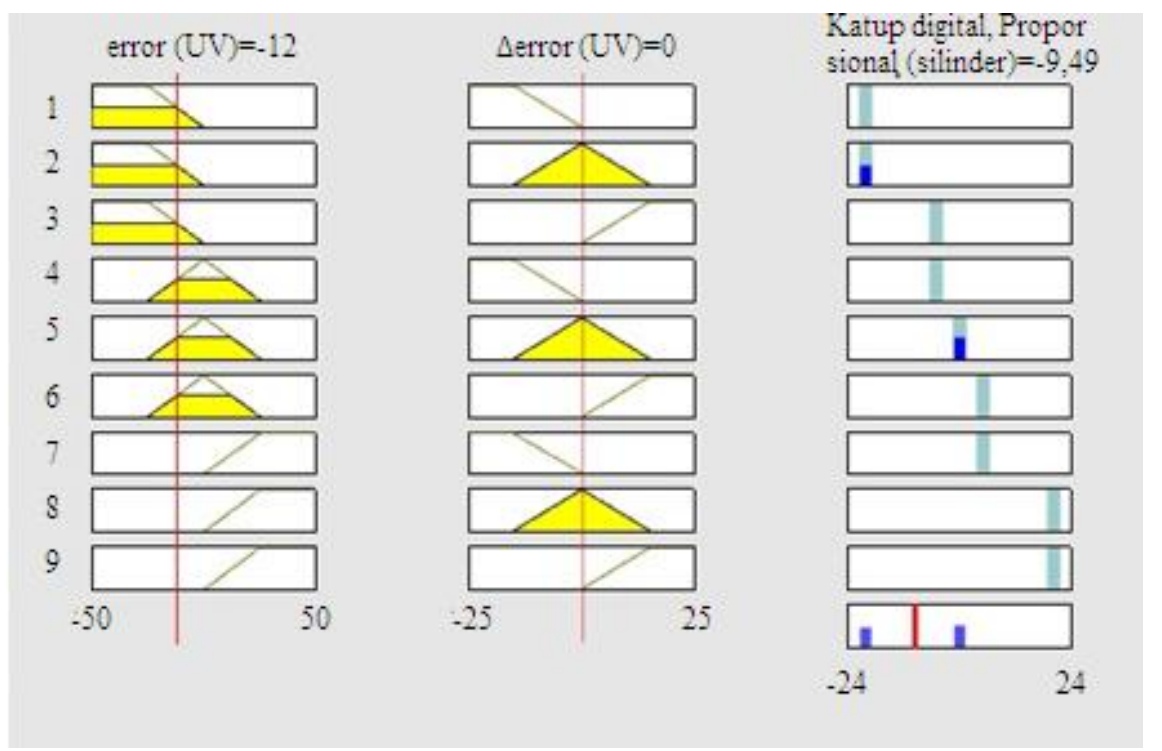

Gambar 11. Tampilan aturan fuzzy dengan keluaran turun

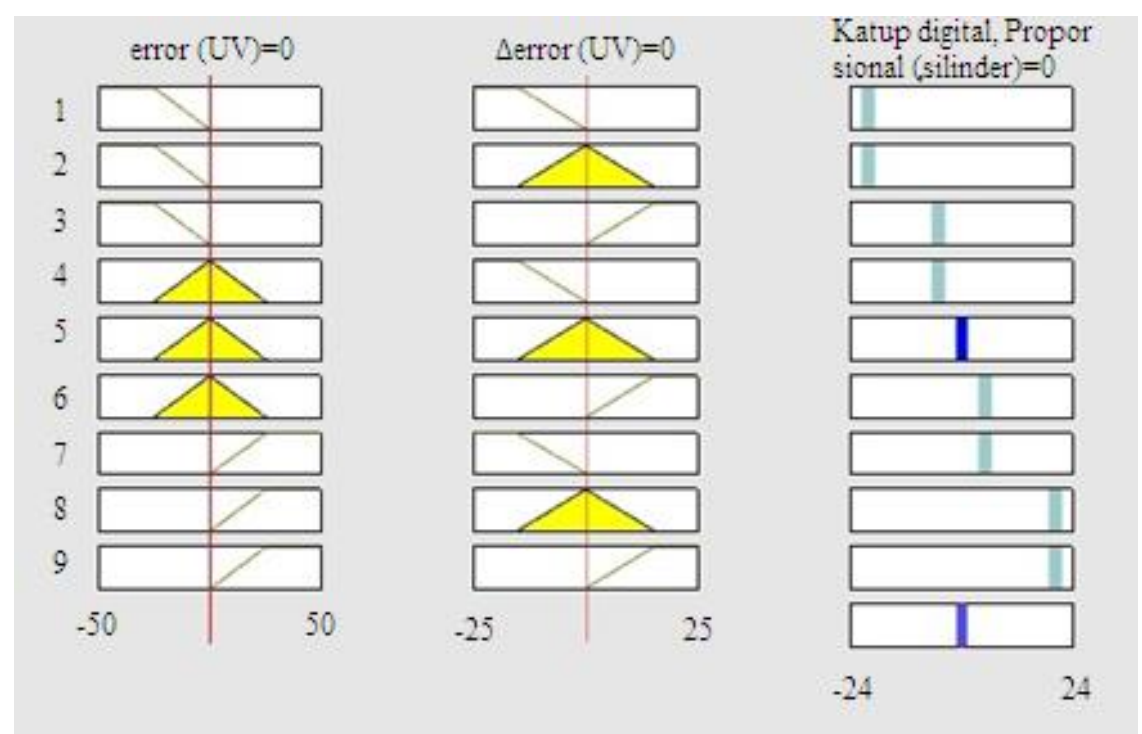

Gambar 12. Tampilan aturan fuzzy dengan keluaran stop

\section{HASIL DAN PEMBAHASAN}

Pada tahap ini dilakukan pengujian perangkat keras dan lunak. Pengujian perangkat keras diawali pada sensor UV. Sensor UV bekerja membaca indek UV dan infra-red sekaligus dalam satu waktu. Pengujian sensor UV dilakukan pada kondisi cuaca mendung dan cerah dengan menggerakan sensor secara manual dari $-22,5^{\circ} \mathrm{ke} 0^{\circ}$. Gambar 13a menunjukkan grafik hasil pengujian sensor pada kondisi mendung untuk cahaya matahari yang mengandung UV. Terlihat pembacaan pengolahan data perangkat lunak menghasilkan nilai indek UV tidak stabil (berosilasi) setiap durasi 2 detik. Gambar 13b menunjukkan grafik hasil pengujian sensor pada kondisi cerah. Terlihat menghasilkan nilai indek UV lebih stabil dibandingkan dengan kondisi mendung. Gambar 13c menunjukkan grafik hasil pengujian sensor pada kondisi mendung untuk cahaya matahari yang mengandung infra-red. Terlihat pembacaan pengolahan data perangkat lunak menghasilkan nilai indek infra-red tidak stabil (berosilasi) setiap durasi 2 detik. Gambar 13d menunjukkan grafik hasil pengujian sensor pada kondisi cerah. Terlihat menghasilkan nilai indek infra-red lebih stabil dibandingkan dengan kondisi mendung. Grafik hasil pembacaan satu waktu antara UV dan infra-red terlihat memiliki pola yang sama. Pada penelitian ini pembacaan data yang digunakan sebagai umpan balik pengambilan keputusan fuzzy adalah indek UV, mengacu pada 
Persamaan (1). Sedangkan nilai setpoint 3 digunakan sebagai acuan sistem solar tracker, berdasarkan tingkat rata-rata pembacaan indeks UV di Kota Bandung pada kondisi cerah seperti terlihat pada grafik.
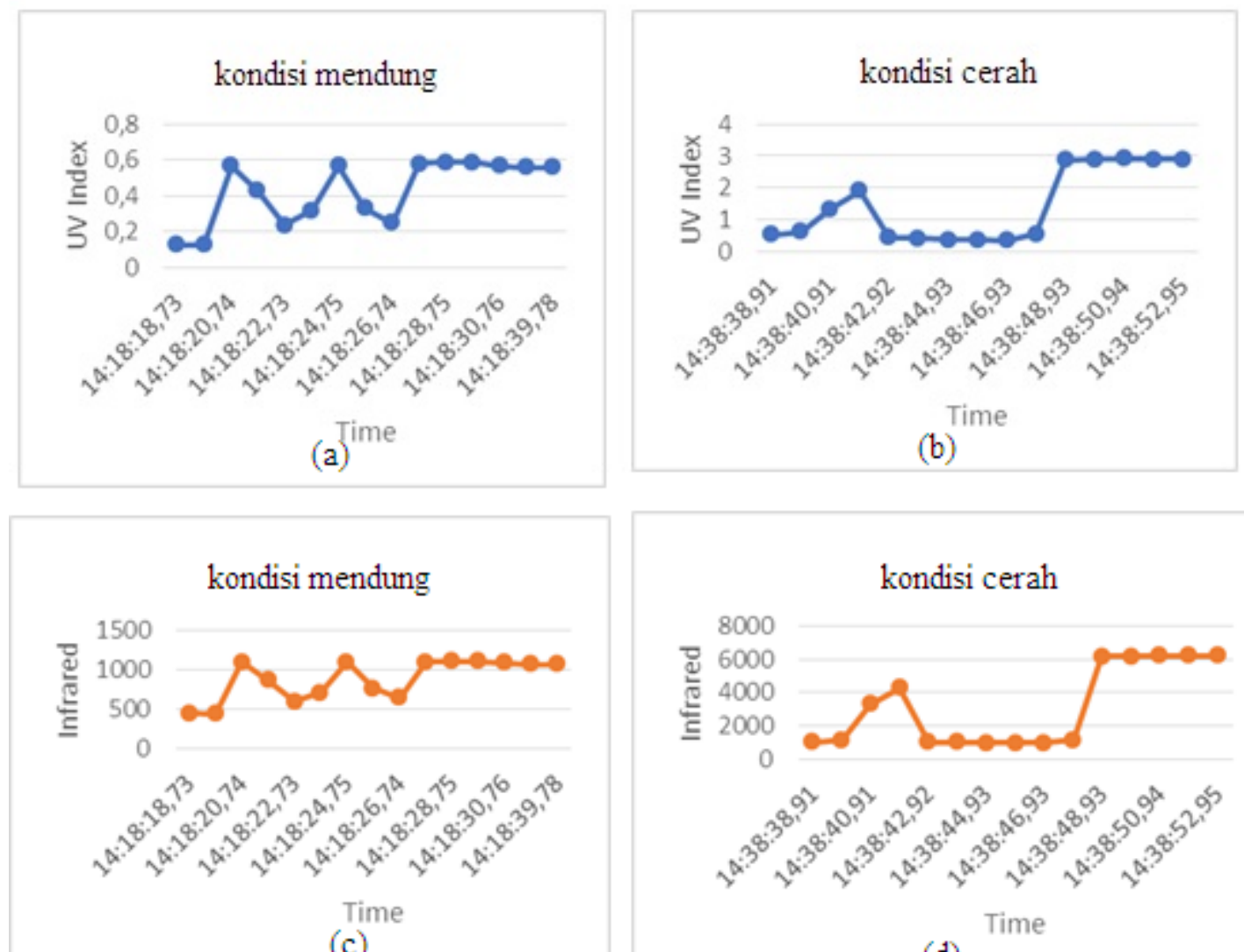

(c)

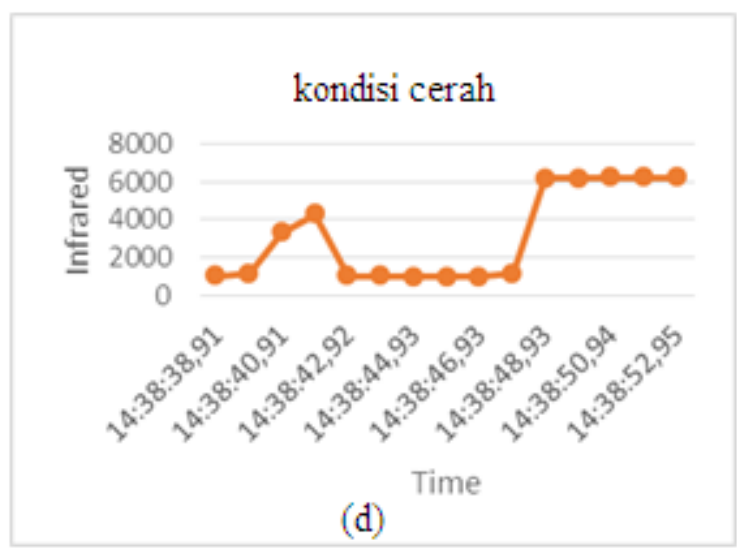

Gambar 13. Hasil pengujian dan pengukuran sensor UV

Pengujian sistem solar tracker merupakan kombinasi perangkat lunak algoritma fuzzy yang dirancang dengan perangkat keras elektronik. Pengujian kombinasi ini bertujuan untuk mengetahui respon dinamik silinder pneumatik pada solar tracker. Pengujian dilakukan dengan skenario tanpa gangguan, seperti ditunjukkan pada Gambar 14.

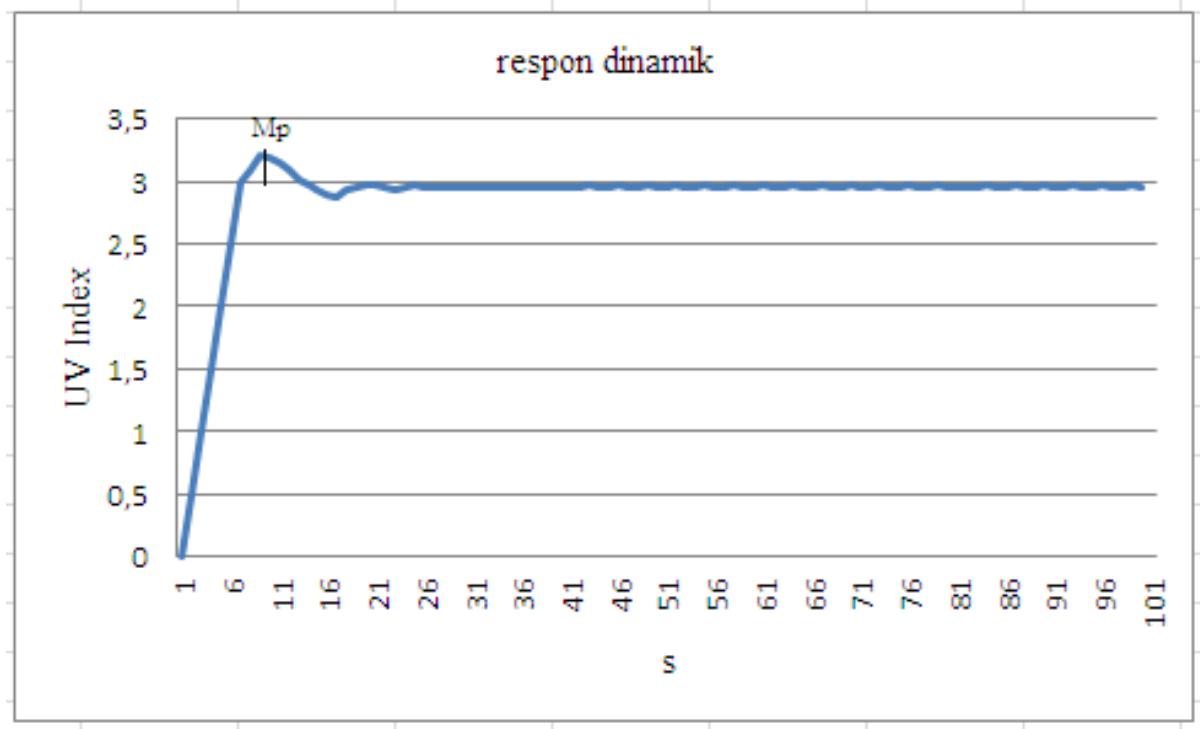

Gambar 14. Grafik respon dinamik silinder pneumatik pada solar tracker 
Dari Gambar 14 didapatkan nilai time settling atau $\mathrm{t}_{\mathrm{s}}$ dan error steady state. Setpoint indek UV=3 ditanam secara program di mikrokontroler. Berikut penjelasan perhitungannya.

a. Time settling didapatkan $\mathrm{Ts}=17 \mathrm{~s}$;

b. Error steady state yang didapatkan:

$$
\text { ess }=\frac{(3,05-3)}{3} \times 100 \%=1,6 \%
$$

c. Maksimum Overshoot (Mp) merupakan nilai tertinggi dari grafik adalah 3,16 maka :

$$
M p=\frac{(3,16-3)}{3} \times 100 \%=5,3 \%
$$

Berdasarkan prosentase kesalahan yang ditetapkan pada penelitian ini adalah ess maksimum 5\% dan Mp maksimum 25\%. Sehingga nilai pengujian sistem pada setpoint 3 yang diperbolehkan adalah $2,85 \leq$ ess $\leq 3,15$ dan $2,25 \leq \mathrm{Mp} \leq 3,75$. Grafik hasil pengujian Gambar 14 (garis tebal warna biru) memperlihatkan nilai keluaran mencapai steady state 2,95 pada time settling $17 \mathrm{~s}$. Sehingga diperoleh prosentasi nilai ess 1,6\%, seperti ditunjukkan pada Persamaan (4). Sedangkan, nilai keluaran overshoot 3,16 pada time peak 10s. Sehingga diperoleh prosentasi nilai Mp 5,3\%, seperti ditunjukkan pada Persamaan (5).

\section{KESIMPULAN}

Pengaturan otomatis aktuator silinder pneumatik pada solar tracker menggunakan fuzzy sugeno telah berhasil dirancang dan diimplementasikan. Hasil pengujian menunjukkan bahwa sistem dapat mempertahankan setpoint dengan respon dinamik overshoot $5,3 \%$ dan error steady state 1,6\%. Penelitian lebih lanjut yang dapat dilakukan adalah dengan mengembangkan metode fuzzy, ANFIS untuk menghasilkan respon yang lebih baik dan cepat.

\section{UCAPAN TERIMA KASIH}

Tim peneliti mengucapkan terima kasih kepada P3M Politeknik Negeri Bandung atas pendanaan penelitian melalui skema Peningkatan Kapasitas Laboratorium dengan SK Nomor B/186.21/PL1.R7/PG.00.03/2020.

\section{DAFTAR PUSTAKA}

[1] Smirnov, A.A., Vozmilov, G., and Romanov, P.A., (2019). "Comparison of Discrete Sun Tracking Methods for Photovoltaic Panels", International Conference on Industrial Engineering, Applications and Manufacturing (ICIEAM), Sochi, Russia, pp. 1-5.

[2] Díaz, A., Garrido, R., and Soto-Bernal, J.J., (2019). "A Filtered Sun Sensor for Solar Tracking in HCPV and CSP Systems", in IEEE Sensors Journal, 19, pp. 917-925.

[3] Rouzbeh, B., Bone, G.M., and Ashby, G., (2018)."High-Accuracy Position Control of a Rotary Pneumatic Actuator", in IEEE/ASME Transactions on Mechatronics, 23, pp. 2774-2781.

[4] Rahmanian, E., Akbari, H., and Sheisi, G.H., (2017). "Maximum Power Point Tracking in Grid Connected Wind Plant by Using Intelligent Controller and Switched Reluctance Generator", in IEEE Transactions on Sustainable Energy,8, pp.1313-1320.

[5] Jabr, H.M., Lu, D., and Kar, N.C., (2011). "Design and Implementation of Neuro-Fuzzy Vector Control for Wind-Driven Doubly-Fed Induction Generator", in IEEE Transactions on Sustainable Energy,2, pp. 404-413.

[6] Chern, T., et al., (2014). "Excitation Synchronous Wind Power Generators With Maximum Power Tracking Scheme", in IEEE Transactions on Sustainable Energy, 5, pp. 1090-1098.

[7] Cui, Z., Song, L., and Li, S., (2017). "Maximum Power Point Tracking Strategy for a New Wind Power System and Its Design Details", in IEEE Transactions on Energy Conversion, 32, pp. 1063 1071. 
[8] Lin, Z., Zhang, T., Xie, Q., and Wei, Q., (2018). "Intelligent Electro-Pneumatic Position Tracking System Using Improved Mode-Switching Sliding Control With Fuzzy Nonlinear Gain", in IEEE Access, 6, pp. 34462-34476.

[9] Amelia, A.R., et al (2019). "Technologies of solar tracking systems: A review", IOP Conf. Series: Materials Science and Engineering 1st International Symposium on Engineering and Technology (ISETech), 767, pp. 1-10.

[10] Smirnov, A.A., Vozmilov, G., and Sultonov. O.O., (2018). "Investigating t he Effectiveness of Solar Tracking for a PV Facility in Chelyabinsk", Int. Conf. On Industrial Engineering, Application and Manufacturing.

[11] Hamid, A.R., Azim, K., and Bakar, M.H., (2017). "A review on Solar Tracking System", eProceeding National Innovation and Invention Competition Through, pp 1-9.

[12] Smirnov, A.A., Malugin, S.A., and Bakanov, A.V., (2017). "Designing Integrated PV Facility with Dual-axis Solar Tracking System Mounted on the South Building Face", Int. Conf. On Industrial Engineering, Application and Manufacturing, pp. 1-4.

[13] Sumathi, V., Jayapragash, R., Bakshi, A., and Akella, P.K., (2017). "Solar Tracking Methods to Maximize PV System Output - A review of the Methods Adopted in Recent Decade", Renewable and Sustainable Energy Reviews, 74, pp. 130-138. 